\title{
CHAPTER 5 \\ ASSESSMENT OF THE RISK PROFILE OF UKRAINIAN BANKS BY THE METHOD OF STRUCTURAL-FUNCTIONAL GROUPS
}

\section{Zarutska O. P.}

\section{INTRODUCTION}

Improving risk management systems in the banking system is an important scientific and practical task. The complexity of risk assessment tools has increased significantly over the past years. Banks use modern mathematical approaches to study loss statistics and identify the greatest risks in their activities. The profile of risks is determined by the specific conditions of the activity of each particular bank. The profile of risks may vary significantly between different banks. The factors of forming the profile of risks are at the margin level and the micro level.

The National Bank of Ukraine defines a profile of risks as an assessment of the bank's vulnerability to risks in aggregated form and in the context of all types of risks carried out on a certain date based on current or projected assumptions. Requirements for risk management systems are set forth in the Regulation on the organization of a risk management system in banks of Ukraine and banking groups ${ }^{1}$.

According to the requirements of the National Bank of Ukraine, each bank should determine the risk level (Risk Capacity) in its internal documents. The permissible level of risk characterizes the maximum risk that the bank can assume for all types of risks. This level depends on the size of the bank's capital and risk management systems.

Each bank determines its own risk appetite using risk-appetite indicators. The risk appetite is defined as the aggregate value for all types of risks and separately for each of the risks. Risk appetite is calculated in advance within the acceptable level of risk. The individual level of risk appetite for each type of risk is the basis for setting limits.

\footnotetext{
${ }^{1}$ Polozhennia pro organizatsiu systemy upravlinnia rizikamy v bankah Ukrainy ta bankivskih grupah: Postanova Natsionalnogo banku Ukrainy vid 11.06.2018 № 64 [Requirements for risk management systems are set forth in the Regulation on the organization of a risk management system in banks of Ukraine and banking groups].
} 
Each bank decides on the appropriateness of accepting individual risks in order to achieve strategic goals and business plan. The overall level of risk appetite should also be in line with the bank's business model. Risk appetite for each type of risk is determined by quantitative indicators that depend on the type of risk. Risk appetite is also affected by qualitative requirements: banking documentation on risk management, description of bank processes that determine the key points, in which the bank may be exposed to significant risks, qualifications of the bank's staff. Banks choose models and risk assessment tools, taking into account business needs, the volume of operations, peculiarities of activity.

Each bank must develop an appropriate risk management culture to implement the established conditions of activity. The risk management culture determines approaches to compliance with the bank's principles, rules, norms of the bank for taking risks and managing risks. According to the established requirements, banks are obliged to create effective information systems and qualitative statistical data for evaluation and support of processes.

Banks organize risk management systems based on the division of responsibilities between bank units using the model of three protection lines. The first line of defence is at the level of business units of the bank and support units of the bank. These departments take risks and bear responsibility for them and report on the current management of such risks. The second line is at the level of the risk management unit and the compliance control unit. The third line of defence is at the level of the internal audit unit for verifying and evaluating the effectiveness of the risk management system.

Approaches to the definition of the profile of risks are actively formed in 2019 after the introduction of new regulatory requirements. In our opinion, the particulars of a business model of a particular bank should determine the approaches of banking supervision to the profile of risks. It is necessary to classify banks by the nature of business models. We suggest using the self-organized map Kohonen (SOM) ${ }^{2}$ to formalize the characteristics of the banking system and identify the profile of risks of Ukrainian banks.

\footnotetext{
${ }^{2}$ Kohonen, T. (2013). Essentials of the self-organizing map. Neural Networks, Vol. 37, 52-65.
} 


\subsection{The main risks in the activities of banks of Ukraine}

The classification of bank risks in the regulatory documents of the National Bank of Ukraine has changed over the past years. The nine main types of bank risks are defined in the Methodological Recommendations on the Organization and Functioning of Risk Management Systems in Banks of Ukraine ${ }^{3}$.

Six types of risks are called quantitative and are measured using mathematical methods. Quantitative risks are called financial risks. The system of financial risks includes the following types: credit risk, liquidity risk, interest rate risk, market risk, currency risk, and operational-technological risk. Qualitative risks cannot be investigated with accuracy as quantitative. Qualitative (non-financial risks) includes the following types: reputational risk, legal risk, strategic risk.

In 2018, the risk classification has changed slightly.

According to the current regulatory requirements, each bank must carry out a comprehensive assessment of the following essential types of risks:

1) credit risk;

2) liquidity risk;

3) interest rate risk of the bank book;

4) market risk;

5) operational risk;

6) compliance risk;

7) other significant types of risks.

Currency risk was not included in the list of major risks. Currency risk is measured due to non-compliance of assets and liabilities in foreign currency. It is determined by elements of credit risk, liquidity risk, and other risks. Banks may include currency risk in the list of major risks if it significantly affects financial stability. Reputation risk, legal risk, and strategic risk are combined in compliance risk in the new classification. Next, we will consider individual risks in the banking system of Ukraine.

Credit risk is defined as the probability of occurrence of losses or additional losses as a result of the failure of the debtor to assume obligations in accordance with the terms of the contract. Credit risk is the greatest risk for most banks. The credit risk of modern banks is

\footnotetext{
${ }^{3}$ Metodychni rekomendatsii shchodo organizatsii ta funktsionuvannia system rizik-menedzhmentu $\mathrm{v}$ bankah Ukrainy: Postanova Natsionalnogo banku Ukrainy vid 02.08.2004 № 361 [Methodological Recommendations on the Organization and Functioning of Risk Management Systems in Banks of Ukraine].
} 
associated with the accumulation of non-performing loans (NPL) in the balance sheets of banks. During the last years of crisis, many borrowers of banks have not fulfilled their obligations. The size of non-performing loans was also influenced by the rapid drop in the national currency rate. Borrowers who did not have foreign currency earnings were unable to pay for loans in foreign currency.

According to the Financial Stability Report of the National Bank of Ukraine, at the end of 2017, NPL accounted for 54.6\% of the total assets of banks ${ }^{4}$. Banks are working with programs for restructuring loans, ways of settling the accumulated debt. The reduction in NPL occurs at a very slow pace. The cost of collateral, as a rule, is insignificant and cannot compensate damages from non-repayment of loans.

The high interest rate on loans damages the further provision of new qualitative loans. The analysis of the indicators of the banking system is carried out using statistical data on the website of the National Bank of Ukraine $^{5}$. According to the reporting at the beginning of 2019, the interest rate on individual loans is $28.6 \%$. Loans to individuals are provided in national currency exclusively. For corporate clients, in national currency, the interest rate is $20.5 \%$. Rates for foreign currency loans are $6 \%$. These loans are available only to clients with currency earnings. Demand for business loans is very limited.

Lending to the population in Ukraine grew by more than $35 \%$ in 2018. Banks provide loans to households for the purchase of consumer goods. Overdraft loans for payment cards are developing the fastest. Over the past two years, the average loan size has increased by $60 \%$, and the number of loans issued has increased by only $18 \%$. The circle of borrowers is expanding slowly. Specialists associate the development of consumer lending with a reduction in the solvency of the population. High interest rates hinder the development of mortgages.

The main problem of credit risk is the concentration of assets in the three largest state-owned banks: PRIVATBANK, OSCHADBANK, UKREXIMBANK. The assets of these banks occupy almost half of the assets of the entire banking system.

As of the beginning of 2019, the share of PRIVATBANK's assets amounted to $21 \%$ of the total assets of the system. The share of NPL of PRIVATBANK is up to $83 \%$. The share of non-performing loans in the

\footnotetext{
${ }^{4}$ Zvit pro finansovu stabilnist za gruden 2018 (Natsionalnii bank Ukrainy) [Financial Stability Report].

${ }^{5}$ Statystyka Natsionalnogo banku Ukrainy (za danymy ofitsiinogo saitu) [Statistics of the National Bank of Ukraine].
} 
entire banking system is reduced to $45 \%$ without taking PRIVATBANK into account. The share of assets of OSCHADBANK is $16 \%$. UKREXIMBANK, the third-largest state bank, holds $12 \%$ of the total assets of the banking system. The share of NPL for banks OSCHADBANK and UKREXIMBANK is 55\%. The problem of a large proportion of problem assets of state-owned banks is an important challenge for the banking system development strategy.

A significant part of the assets of Ukrainian banks is concentrated in government securities of domestic government bonds. Government securities are considered to be highly liquid assets in the world. The risks of Ukrainian bonds of an internal state loan are determined by high risks of the country. The concentration of bank assets in this instrument is high and is constantly increasing. At the beginning of 2019, the share of government bonds is an average of $30 \%$ of the total assets of the banking system.

The level of dollarization of the banking sector in Ukraine remains high in recent times. During the past decade, the share of deposits and loans in foreign currency was not lower than $31 \%$. The population retains a significant portion of foreign currency savings. Banks have a lot of free currency funds. The level of dollarization differs considerably in groups of banks. Leading banks with state Russian capital have the highest value. The foreign currency loans of these banks reach $90 \%$ of the portfolio.

Ukrainian banks do not have high liquidity risks in recent years. Liquidity risk is defined as the probability of occurrence of losses or additional losses as a result of the bank's failure to provide financing for the growth of assets and fulfilment of its obligations in due time. Most banks have a high volume of highly liquid assets, cash balances and resources on a correspondent account with the National Bank of Ukraine. Banks do not have the ability to develop credit operations.

The problem of liquidity of Ukrainian banks is the lack of long-term resources. In 2014-2017, there was a significant decrease in the number of banks. At the same time, the volume of funds of individuals has decreased. The banking system has lost the trust of depositors and restores it gradually. To assess the liquidity of banks, it is necessary to analyse the structure of the resource base.

Households are the main net lender of the banking sector. The volumes of funds of individuals in banks are increasing but the terms of their placement have decreased significantly. The balances on current 
accounts form the bulk of the increase in population funds in banks. The deposit base of individuals is growing more slowly than the balances on loans issued. The ratio of loans and deposits (loan-to-deposit ratio, LtD) is $36 \%$. The aggregate debt burden on households is only $6 \%$ of gross domestic product.

Short-term resources dominate the structure of the banks' liabilities. Funds with a maturity of up to 1 month occupy $62 \%$ of the resource base. Commitments up to 1 month in UAH amount to as much as $75 \%$. The structure of liabilities differs from the structure of assets. Assets with maturity over 1 month exceed 64\%. Assets in the national currency for more than 1 month make up 67\%. At the expense of short-term funds, banks are loaned for much longer periods. Banks provide longterm loans at short-term funds. Balances on salary and social payments are growing at a higher pace.

The funds of the business entities are also volatile. Almost $70 \%$ of all funds are balances on current accounts. Since 2014, their share in total business has increased substantially. The breakdown of the maturity between assets and liabilities puts banks at risk of liquidity. In periods of stability, banks can rely on short-term funds, but in crisis situations, such a structure is extremely risky. The flow of funds from current accounts can take place almost instantaneously.

The gap between the dates of assets and liabilities affects the interest rate risk. Interest rate risk is defined as the probability of occurrence of losses or shortfall of the planned revenues as a result of the effect of unfavourable changes in interest rates on the bank book. The interest rate risk of a bank book affects the economic value of the bank's capital and the net interest income of the bank.

When rates in the economy begin to increase, then the cost of most resources increases during the month. It takes much longer to increase the value of banks' assets. Unbalanced resource base reduces interest spread, net interest income and net profit of banks. Banks need to create more incentives to attract long-term customers. The difference between the rates for long-term and short-term deposits should be greater.

Analysis and comparison of the structure of assets and liabilities allow us to assess liquidity risk, interest rate risk, and operational risk. Operational risk is defined as the probability of occurrence of losses or lack of planned revenue due to defects or errors in the organization of internal processes, intentional or unintentional actions of bank 
employees or other persons, failures in the work of information systems of the bank or as a result of the influence of external factors.

Some banks have traditionally large residues of highly liquid assets. An increased share of cash in assets and current liabilities may indicate an increased risk of legalization and laundering of proceeds from crime. A large share of cash transactions requires increased attention of banks. The profile of risks of some banks is associated with a high proportion of interbank assets or liabilities.

The market risk of a bank can be estimated by calculating the share of funds in securities, income and expenses associated with market instruments. Market risk is defined as the probability of occurrence of losses or lack of planned revenues as a result of unfavourable changes in foreign exchange rates, interest rates, and the value of financial instruments.

An important role is played by the distribution of assets and liabilities by type of currency. The level of dollarization of Ukrainian banks is decreasing very slowly. The high share of foreign currency loans creates risks of a sharp deterioration in the quality of the loan portfolio and the receipt of significant losses under adverse conditions.

The following is a set of indicators used to assess the risk profile of the bank using the method of structural-functional groups. The choice of indicators is determined and limited by the parameters of the published statistical reporting of banks. The National Bank of Ukraine periodically publishes aggregated balance data of banks. By 2018, the balance sheet statistics were posted on the National Bank of Ukraine website quarterly. Subsequently, the reporting is updated on a monthly basis.

We will investigate the risk profile of banks using the system of indicators presented in Table 1. Individual indicators characterize one type of risk, others reflect different aspects of financial sustainability and risk.

The ratio of the net asset value of the bank to the total assets of the system (A-s) is calculated as the ratio of the net assets of the bank to the net assets of the system. Indicator characterizes the bank's position in the banking market. The size of the bank's assets significantly affects the characteristics of its business model and risk profile.

The ratio of assets in foreign currency to net assets (VCA) characterizes the level of dollarization of the balance sheet and currency risk of the bank. The ratio of the difference between assets and liabilities in foreign currency to net assets (VL) characterizes the discrepancy of 
attracted and allocated resources in foreign currency and the currency risk of the bank. Foreign exchange risks are manifested through various aspects of banks' operations and increase credit risk, liquidity risk, interest, and other risks.

Table 1

The system of indicators for studying the risk profile of banks

\begin{tabular}{|c|l|l|}
\hline № & Indexes & \multicolumn{1}{|c|}{ Indicator content } \\
\hline 1 & A-s & The share of net assets of the bank in total assets of the system \\
\hline 2 & VCA & The share of assets in foreign currency \\
\hline 3 & VL & The share of currency position in assets \\
\hline 4 & ROA & Return on assets \\
\hline 5 & RA & The ratio of provisions for credit risk to assets \\
\hline 6 & VR & The ratio of expenses for the formation of provisions for assets \\
\hline 8 & SAUN & The share of corporate loans in national currency in assets \\
\hline 7 & SAUI & The share of corporate loans in foreign currency in assets \\
\hline 9 & SAFN & The share of retail loans in national currency in assets \\
\hline 10 & SAFI & The share of retail loans in foreign currency in assets \\
\hline 11 & SAMN & The share of interbank loans in national currency in assets \\
\hline 12 & SAMI & The share of interbank loans in foreign currency in assets \\
\hline 13 & SAV & $\begin{array}{l}\text { The share of cash and balances on correspondent accounts } \\
\text { in assets }\end{array}$ \\
\hline 14 & SAC & The share of securities in assets \\
\hline 15 & SPUS & The share of fixed-term funds of legal entities in liabilities \\
\hline 16 & SPUP & The share of current assets of legal entities in liabilities \\
\hline 17 & SPUN & The share of legal entities in national currency in liabilities \\
\hline 18 & SPUI & The share of legal entities in foreign currency in liabilities \\
\hline 19 & SPFS & The share of fixed-term funds of personal funds in liabilities \\
\hline 20 & SPFP & The share of current funds of personal funds in liabilities \\
\hline 21 & SPFI & The share of personal funds in national currency in liabilities \\
\hline 22 & SPFN & The share of personal funds in foreign currency in liabilities \\
\hline 23 & SPMN & The share of interbank loans in national currency in liabilities \\
\hline 24 & SPMI & The share of interbank loans in foreign currency in liabilities \\
\hline 25 & VA & The ratio of administrative costs to assets \\
\hline 26 & KD & The ratio of net commission income to assets \\
\hline 27 & TD & The ratio of trade income to assets \\
\hline 28 & PD & The ratio of interest income to interest-bearing assets \\
\hline 29 & PV & The ratio of interest expense to interest obligations \\
\hline 30 & PM & Net interest margin \\
\hline 31 & CA & Balance sheet assets ratio \\
\hline & & \\
\hline
\end{tabular}


The profitability of assets (ROA) is calculated as the ratio of the bank's net income to assets. The indicator characterizes the overall performance of the bank. This is one of the most important indicators of a successful business model selection.

The ratio of provisions for credit risk to assets (RA) characterizes the quality of assets of the bank. This indicator is also an important characteristic of the financial stability of the bank. The ratio of expenses on the formation of reserves to assets (VR) characterizes the quality of assets in the current year. This indicator differs from the previous one and takes into account only the current expenses for the formation of reserves. To measure asset quality, we use both indicators.

Characteristics of the loan portfolio we can get by structural indicators. The aggregated reporting of banks shares loans of individuals and business entities in national and foreign currencies. On the basis of this information, the following indicators are calculated: the share of corporate loans in national currency in assets (SAUN), the share of corporate loans in foreign currency in assets (SAUI), the share of retail loans in national currency in assets (SAFN), the share of retail loans in foreign currency assets (SAFI).

To assess credit risk and liquidity risk, it is important to examine all assets of banks. Insufficient development of credit operations forms a group of banks with significant assets located on the interbank market. The indicator of the share of interbank loans in national currency in assets (SAMN) characterizes the business models of banks with surplus funds in the national currency. The funds of banks are directed to the interbank market, and not to the real economy. Indicator of the share of interbank foreign currency loans in assets (SAMI) allocates banks with another risk profile. Often such banks are participants of foreign banking groups.

The share of cash and cash balances on correspondent accounts in assets (SAV) characterizes the share of highly liquid assets of banks. The low level of this indicator indicates the risk of instant liquidity. The high level of the indicator testifies to the ineffective policy of asset and liability management.

The share of assets in securities (SAC) reflects the problem of concentration of assets in the bonds of the domestic state loan. A significant part of the assets in securities provides the bank with a stable profit, but it can cause losses in the long run. 
The assessment of the resource base of banks requires a detailed study of the structure of liabilities. We will use the following indicators: the share of fixed-term funds of legal entities in liabilities (SPUS), the share of current assets of legal entities in liabilities (SPUP), the share of legal entities in national currency in liabilities (SPUN), the share of legal entities in foreign currency in liabilities (SPUI), the share of fixed-term funds of personal funds in liabilities (SPFS), the share of current assets of personal funds in liabilities (SPFP), the share of personal funds in national currency in liabilities (SPFN), the share of personal funds in foreign currency in liabilities (SPFI).

The parity of the share of interbank loans in national currency in liabilities (SPMN) and the share of interbank loans in foreign currency in liabilities (SPMI) characterize the feature of the bank's resource base. Banks with foreign shareholders for a long period of time had a significant amount of borrowed interbank resources. Interbank lending in the national currency cannot function as a stable resource base.

We research the business model of the bank and the profile of risks, taking into account the main sources of income and the direction of expenditure. The following indicators are used for the major factors of profit generation: the ratio of administrative costs to assets (VA), the ratio of net commission income to assets (KD), and the ratio of trade income to assets (TD). Banks with significant amounts of retail loans often have an increased level of administrative and commission income.

The parameters of interest policy determine the place of the bank in the market and the profile of its risks. The ratio of interest income to interest assets (PD) allows you to estimate the level of the average rate of allocation of resources.

The ratio of interest expense to interest-bearing liabilities (PV) characterizes the rate of attraction of resources. The net interest margin $(\mathrm{PM})$ is calculated as the ratio of net interest income to average assets. This indicator characterizes the devaluation of the bank's interest rate policy.

The ratio of balance capital to assets (CA) characterizes the degree of security of the bank. Capital is the main source of coverage of bank risks. The largest value of this indicator is observed in small banks. Their ability to increase the size of assets is limited, compared to large banks.

The system of indicators describes the structural features of assets and liabilities of each bank for each reporting date. We used an array of data to build the self-organized map Kohonen (SOM). Mapping is done 
using the Viscovery SOMine software package. More information on the use of maps can be found in the literature ${ }^{678}$.

\subsection{Distribution of risks by structural-functional groups of banks}

The essence of the method of structural-functional groups is the formation of homogeneous groups of banks according to the values of financial indicators. At the same time, the value of all indicators of a multidimensional database is taken into account. The results are presented in the form of a geographic map. Neighbouring banks on the map have many common features. Remote groups combine banks that are significantly different. Homogeneous objects are automatically merged into groups.

We found stable bonds between banks within structural and functional groups according to research data from 2003. The formats of the financial statements are systematically changing. The current database has been formed since 2009. The position of groups on the map as of 01.01.19 is shown in Fig. 1.

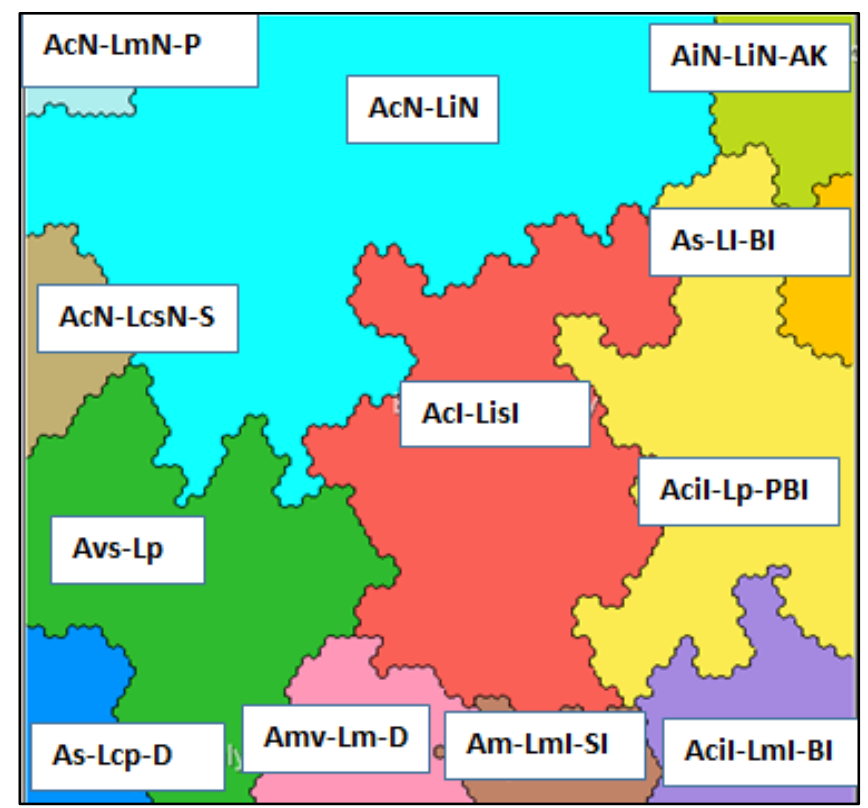

Fig. 1. Placement of structural-functional groups on the SOM as of 01.01.2019

\footnotetext{
${ }^{6}$ Kohonen, T. (2001). Self-Organizing Maps. Berlin Heidelberg: Springer-Verlag.

${ }^{7}$ Severin, E. (2010). Self-organizing maps in corporate finance: Quantitative and qualitative analysis of debt and leasing. Neurocomputing, 73 (10-12), 2061-2067.

${ }^{8}$ Zarutska, O. P. (2018). Structural-functional analysis of the Ukraine banking system. Financial Markets, Institutions and Risks, vol. 2, pp. 79-96.
} 
Each map point represents the location of one or more banks for the entire study period. Banks with homogeneous characteristics are combined into groups with the corresponding colour. The presented map includes twelve groups of different sizes and number of banks.

The most balanced indicators are banks in the centre of the map. The banks at the diagonal distance are most different. Characteristics of each group are presented in Table 2.

Table 2

\section{Characteristics of structural-functional groups as of 01.01.2019}

\begin{tabular}{|c|l|l|}
\hline № & \multicolumn{1}{|c|}{ Groups } & \multicolumn{1}{|c|}{ Brief description } \\
\hline 1 & AcN-LiN & $\begin{array}{l}\text { The small banks with average characteristics, corporate } \\
\text { business with retail financing in the national currency }\end{array}$ \\
\hline 2 & AcI-LisI & $\begin{array}{l}\text { The small banks with average characteristics, corporate } \\
\text { business with retail financing in foreign currency }\end{array}$ \\
\hline 3 & AciI-Lp-PBI & The large banks with currency and credit risks \\
\hline 4 & As-LI-BIP & $\begin{array}{l}\text { The largest banks with credit and currency risks and } \\
\text { securities in assets }\end{array}$ \\
\hline 5 & AiN-LiN-AK & The banks of retail lending in the national currency \\
\hline 6 & AciI-LmI-BI & The large banks with foreign currency liabilities \\
\hline 7 & Am-LmI-SI & $\begin{array}{l}\text { The small banks with increased interbank assets and } \\
\text { liabilities in foreign currency }\end{array}$ \\
\hline 8 & Amv-Lm-D & The small banks with interbank operations \\
\hline 9 & AcN-LmN-P & The troubled banks \\
\hline 9 & AcN-LcsN-S & The small banks with a limited range of customers \\
\hline 8 & As-Lcp-D & $\begin{array}{l}\text { The banks with short-term liabilities and securities in } \\
\text { assets }\end{array}$ \\
\hline 4 & Avs-Lp & The banks with securities in assets \\
\hline
\end{tabular}

The group of small banks with average characteristics, corporate business with retail financing in the national currency (AcN-LiN) occupies the centre of self-organization map. Usually, this group includes a large number of small banks. Many banks have left the central group of the map over the past two years. Some banks were liquidated. Some banks went to another group of banks with a significant amount of securities.

The group AcN-LiN includes 9 banks with aggregate assets of 3\% of the total assets of the banking system as of 01.01.2019. The number of banks in this group is $11.5 \%$ in the banking system. Banks do not have significant differences from the average. Most of the banks are 
owned by Ukrainian shareholders, attracting household funds and providing small business loans.

The group of small banks with average characteristics, corporate business with retail financing in foreign currency (AcI-LisI) is also located in the centre of the map. The group included many banks in past periods. As of 01.01.2019, this group includes only 9 banks with assets in the amount of $1 \%$ of total assets of the banking system. The group includes banks of Ukrainian and foreign shareholders. Banks provide loans in national and foreign currencies. The indicators of the structure of banks of this group do not differ significantly from the average system indicators.

The group of large banks with currency and credit risks (AciI-LpPBI) combines banks with a high share of assets and liabilities in foreign currency. The credit risks of these banks were reflected in the poor quality of assets and losses. The share of current liabilities is increased. The group includes 9 banks with assets in the amount of $11 \%$ of the total assets of the banking system.

The banks of the eastern part of the map have increased the share of assets in foreign currency (VCA). Banks of the eastern part of the map have more importance of the share of corporate loans and current liabilities in foreign currency. Instead, banks with a high level of corporate deposits and loans in the national currency are in the western part of the map. This characteristic of the risk profile is one of the key features of placing on the map of self-organization.

The largest banks (As-LI-BIP) are located on the north-eastern boundary of the map. The A-s value takes the maximum value in the corresponding segment of the map. As-LI-BIP group constantly includes the following banks: PRIVATBANK, OSCHADBANK, and UKREXIMBANK. The assets of these banks occupy $48 \%$ of the assets of the entire banking system. The banks of this group have low-quality assets and a high share of assets and liabilities in foreign currency. Funds in government bonds occupy a high share in the assets of banks. The largest banks differ significantly from others. They have their own risk profile settings.

Banks of the northern part of the map have a smaller share of free cash in the form of cash and balances on correspondent accounts. Most of these banks' assets are located in loans and securities. Credit risks of banks in the northern part of the map are elevated. For the southern banks, there is a greater risk of liquidity. 
The group of retail lending banks in the national currency (AiNLiN-AK) has declined significantly over the past ten years. In this segment of the map is the maximum value of the SAFN, VA, and KD indicators. Group banks have an increased share of retail loans in the national currency, administrative expenses and commission income. Only 3 banks are included in this group as of 01.01.2019. The aggregate assets of these banks are $1 \%$ of the total assets of the banking system.

The group of large banks in foreign currency (AciI-LmI-BI) includes foreign-owned banks. Banks are located in the south-east of the map. The percentage of interbank foreign currency liabilities (SPMI) reaches the maximum value in this segment of the map. The group includes only 2 banks with assets in the amount of $3.5 \%$ of the total assets of the banking system. The size of the group has declined in recent years. Banks of this part of the map are developing lending operations insufficiently.

Along with this group, there is a group of small banks with increased interbank assets and liabilities in foreign currency Am-LmI-SI. The maximum value of the SAMI index matches the position of the AmLmI-SI group. The group includes a single bank with assets in the amount of $0.1 \%$ of the total assets of the banking system. The number of banks was significant in past periods.

In the group of banks Amv-Lm-D, the volume of interbank loans exceeds the average level of the banking system. Banks work with a limited number of clients. The interest rate policy of such banks is not balanced: the level of rates differs from other banks. This group does not include any bank as of 01.01.2019.

The maximum value of the SPMN of interbank loans raised in the national currency is at a diagonal distance from the SPMI indicator, in the northwest of the map. At this location, there is a group of troubled banks AcN-LmN-P. The banks of this group have high losses and reserves for RA credit risks. A group of troubled banks serves as an indicator of the crisis in the banking system. Many banks went to this group during a significant deterioration of the financial stability of the system. Banks at the stage of temporary administration and liquidation also often fall into the group of troubles. As of 01.01.2019, the group AcN-LmN-P consisted of a single bank with total assets of $1 \%$ of the assets of the system. 
The SAV indicator takes the maximum value in the northwest corner of the map. The corresponding segment is the As-Lsp-D group. Banks attract a lot of current funds. The assets of these banks are dominated by government securities. The yields of interest-bearing assets exceed average values in the market. The group includes 9 banks with aggregate assets of $3 \%$ of the total assets of the system.

A group of banks with a high share of securities assets (Avs-Lp) is also located in the southwest corner of the map. A large number of banks have recently joined this group. The group includes 32 banks with aggregate assets of $30 \%$ of the total assets of the system. Given a large number of banks in this group, it can be assumed that the characteristics of the structure of assets and liabilities of these banks affect the risk profile of the system.

The method of formation of homogeneous structural-functional groups allows estimating the risk profile of each bank on the basis of information about its position on the self-organizing map. Neighbouring banks have similar characteristics of the structure of assets, liabilities, income, expenses. The risk profile of such banks has many common features. The analysis of the risk profile must be carried out within a certain period. For such an analysis, it is useful to use the trajectory of the bank on a self-organizing map.

The trajectories of most small banks are volatile as they are more affected by current changes in balances on balance sheets. Changes in the trajectory of any bank are objective and are due to changes in the values of indicators. The change of strategies and business plan is always reflected in the trajectory of the bank. The close situation of liquidated banks of past periods on the map indicates that there are problems. Banks can use the positive and negative experience of neighbouring banks on a self-organizing map.

The method of structural-functional groups is useful for banking supervision. The study of changes in the size and characteristics of groups allows us to assess the state of the general banking system, the situation of individual groups and individual trajectories of banks. The toolkit of self-organizing maps provides simultaneous consideration of structural characteristics of banks and the visual representation of large data arrays consisting of a large number of parameters.

Modern banking supervision is based on the methodology SREP (Supervisory Review and Evaluation Process). This model is a developed and revised version of the ICAAP (Internal Capital Adequacy 
Assessment Process). ICAAP was created in the framework of Pillar II and directed to research of internal procedures and processes in the bank in order to determine the level of capital adequacy in the long-run to cover all possible risks.

The SREP analysis is based on nine interrelated areas of analysis:

1. The classification of financial institutions (banks) according to the results of cluster analysis.

2. Monitoring of key indicators.

3. Analysis of business model.

4. Assessment of internal governance, as well as an internal control system (ICS).

5. Capital risks and adequacy (ICAAP).

6. Liquidity risks and adequacy.

7. Summarizing total assessment.

8. Definition and communication of regulatory measures.

9. Early intervention of supervision ${ }^{9} 10$.

For a modern system of supervisory measures, a transition from unified to differentiated control methods is required. For larger risks, detailed checks are required. The choice of the supervision regime for a particular bank should be determined by the risks of its activities and the effectiveness of management systems for these risks. Problems of the activities should be equally understandable for bank oversight supervisors and bank managers. The proposed method contributes to the objective assessment of bank risks.

The position of the bank on the organizational chart describes a number of aspects of its problems and risks. Particular attention is needed by groups of banks with high risks. The largest assets of Ukrainian banks are concentrated in As-LI-BI, AsiI-Lp-RBI, Avs-Lr groups. Banks of these groups require increased attention to banking supervision. The main risks are credit and interest risk. The growth of the number of banks in the Avs-Lr group is characterized by features of business models in a particular period, or systemic risk profile. The concentration of banks' assets in government bonds is a significant challenge for the development of the banking system.

\footnotetext{
9 European Central Bank, ECB (2017). SSM SREP Methodology Booklet. Available at: https://www. bankingsupervision.europa.eu/ecb/pub/pdf/ /ssm.srep_methodology_booklet_2017.en.pdf ?508ca0e386f9b913 69820bc927863456

10 Basel Committee on Banking Supervision, BCBS (2008). Principles for sound liquidity risk management and supervision. Available at: http://www.bis.org/publ/bcbs144.pdf
} 


\section{CONCLUSIONS}

The methodology of structural-functional groups of banks provides important advantages for quantitative description of qualitative changes in the financial condition of the banking system and individual banks. An important advantage of the method is the ability to take into account the value of many indicators. We proposed to use indicators of the structure of assets, liabilities, income, and expenses. We also used qualitative performance indicators, reserves for credit risk, asset coverage of capital.

The characteristics of each group can be used to assess the risk profile of banks. Distribution of banks is objective and transparent. The method provides a convenient visualization of the data. Structuralfunctional groups are formed automatically based on the quantitative characteristics of the financial condition of banks. The analysis of the risk system can be used in the banking supervision system.

Each bank can use the published data and calculate its place in the banking system using the method of structural-functional analysis. The bank's path on the self-organizing map reflects changes in the risk profile over time. Each bank can compare its performance with neighbouring banks and model their improvement. The bank's development strategy can be implemented by simulating the future position on the map.

The modern banking system requires the development of lending. The loan portfolios of most banks have a high proportion of nonperforming loans. These banks are on the north side of the map. Major risks are the concentration of assets in government securities. The largest number of relevant banks is located on the north-western part of the map. Some banks have high currency risks. These banks are on the eastern part of the map. The high risks of the banking system are the lack of long-term resources. An increased share of current funds is concentrated on the southern part of the map.

The development of the method of structural and functional groups of banks is possible with the expansion of the list of indicators. We only used data from publicly reported banks. Banking supervision has a more complete structural risk profile of banks.

\section{SUMMARY}

The article is intended to study the main risks of the banking system of Ukraine. The profile of the risks of the banking system and each bank depends on many external and internal factors. The National Bank of 
Ukraine determines the rules for risk management and requirements for the system of internal control. Each bank must understand the main risks of the activity and apply adequate methods of managing them. To determine the risk profiles of banks, we suggest using the method of structural-functional groups. The method allows taking into account the specific conditions of the banking system. The method ensures the formation of homogeneous groups of banks using Kohonen selforganizing maps (SOM). For the construction of homogeneous groups, the reporting data of banks is used. We have found characteristics of the risk profile of banks according to research data in the last fifteen years. The position of the bank on SOM characterizes its risk profile. Stable deviations from the average values indicate the specialization of the bank, its business model, and risk profile.

\section{REFERENCES}

1. Polozhennia pro organizatsiu systemy upravlinnia rizikamy $\mathrm{v}$ bankah Ukrainy ta bankivskih grupah: Postanova Natsionalnogo banku Ukrainy vid 11.06.2018 № 64 [Requirements for risk management systems are set forth in the Regulation on the organization of a risk management system in banks of Ukraine and banking groups]. URL: https://bank.gov.ua/document//download?docId=71600453 (in Ukrainian).

2. Kohonen, T. (2013). Essentials of the self-organizing map. Neural Networks, vol. 37, pp. 52-65.

3. Metodychni rekomendatsii shchodo organizatsii ta funktsionuvannia system rizik-menedzhmentu $\mathrm{v}$ bankah Ukrainy: Postanova Natsionalnogo banku Ukrainy vid 02.08.2004 № 361 [Methodological Recommendations on the Organization and Functioning of Risk Management Systems in Banks of Ukraine]. URL: https:// zakon.rada.gov.ua/laws/show/v0361500-04 (in Ukrainian).

4. Statystyka Natsionalnogo banku Ukrainy (za danymy ofitsiinogo saitu) [Statistics of the National Bank of Ukraine]. URL:https://bank.gov.ua//control/uk/publish/article?art_id=34661442\&c at_id=34798593.

5. Zvit pro finansovu stabilnist za gruden 2018 (Natsionalnii bank Ukrainy) [Financial Stability Report]. URL: https://bank.gov.ua/control/ uk/publish//category?cat_id=32236491(in Ukrainian).

6. Kohonen, T. (2001). Self-Organizing Maps. Berlin Heidelberg: Springer-Verlag. 
7. Severin. E. (2010). Self-organizing maps in corporate finance: Quantitative and qualitative analysis of debt and leasing, Neurocomputing, 73 (10-12), 2061-2067.

8. Zarutska O.P. (2018) Structural-functional analysis of the Ukraine banking system. Financial Markets, Institutions and Risks, vol. 2, pp. 79-96.

9. European Central Bank, ECB (2017). SSM SREP Methodology Booklet. Available at: https://www.bankingsupervision. europa.eu/ecb/pub/pdf//ssm.srep_methodology_booklet_2017.en.pdf?50 8ca0e386f9b913 69820bc927863456.

10. Basel Committee on Banking Supervision, BCBS (2008). Principles for sound liquidity risk management and supervision. Available at: http://www.bis.org/publ/bcbs144.pdf.

\section{Information about the author:} Zarutska O. P.

Doctor of Economic Sciences, Head of Banking and Financial Services Department, University of Customs and Finance, Ukraine 